\title{
DANGERS INVOLVED IN THE EXPLOITATION OF GAME IN N'GAMILAND
}

\author{
By J. J. Malinnson
}

N'gamiland is the native reserve of the Batawana tribe, which has at its head Mahumahati Moremi, the Queen Regent. The headquarters of both the native and of the British administration is at Maun, situated in the Okavango Swamps area. No European is allowed to own property in N'gamiland, and any trading store run by Europeans is leased from the tribe. Queen Moremi has the last say on all matters. There is no known mineral wealth in N'gamiland.

The inaccessibility of N'gamiland is accentuated by hundreds of square miles of surrounding desert. The nearest rail-head is 320 miles to the south-east of Maun, at Francistown, and the road link is difficult and sometimes hazardous. A vehicle with high clearance and good traction is almost essential to combat the sand, and in the absence of filling stations, extra fuel must be carried. There are two other tracks into Maun, one of which comes up from South-West Africa, passing the Lake N'gami panlands, and the other dropping from the north-east, from Panda-Ma-Tenka.

During my recent journey to the Kwaai river, Bushmen from Mababe village offered me skins of cheetah, lion, leopard, civet, genet, and many others. They assured me that they could get as many more as I required. I offered them four times the price if they would bring live specimens, but they said they would far rather take a quantity of dead animals from their steel traps, than attempt to catch a few living ones.

For the African population there is no such thing as an open or closed shooting season, they are allowed to hunt and trap throughout the year. To facilitate this, the trading stores, usually controlled by Europeans, have a good selection of steel-jaw traps and good lengths of suitable wire. These traps can be bought in Maun by anybody and I hear of numerous cases of European hunting parties taking them with them. They would place a few carcasses around the traps at night: by the morning lions, hyaena, and other carnivores would be caught.

Europeans must pay a fee for every animal they intend to shoot. Part of this goes to the Batawana tribe Treasury, part to the Government in Mafeking. But the number of animals for which a hunter buys a licence may bear little relation to what he actually kills. The Game Department is staffed by only two Europeans and a few Africans. It is based on Francistown, 300 miles to the east of the game country.

If N'gamiland were to be allowed to remain a back-water, the outlook would be good. The amount the Africans kill for their own use is negligible, and the presence of the tsetse-fly has been the game's salvation. But the situation is now altered by the scarcity of game concentrations elsewhere and by political strife in countries where safari firms have hitherto flourished. Indeed, N'gamiland is on the brink of being opened up to 
large safari firms. It will be highly publicised and put on the map as a big-game shooting area.

The danger of over-exploitation of the wild life is very real. Roads will be improved, the small air strip at Maun made commercially usable, and the great safari firms enabled to go into full operation. Unless immediate steps are taken to control the coming exploitation, the wild life of N'gamiland faces a gloomy future. 